\title{
ANTIBIOTIC PROPHYLAXIS IN BARIATRIC SURGERY: a continuous infusion of cefazolin versus ampicillin/sulbactam and ertapenem
}

\author{
Álvaro Antônio Bandeira FERRAZ ${ }^{1,2}$, Luciana Teixeira de SIQUEIRA ${ }^{1}$, \\ Josemberg Marins CAMPOS ${ }^{1}$, Guido Correa de ARAÚJO JUNIOR ${ }^{1}$, \\ Euclides Dias MARTINS FILHO' ${ }^{1}$ and Edmundo Machado FERRAZ ${ }^{1}$
}

\begin{abstract}
Background - The incidence of surgical site infection in bariatric patients is significant and the current recommendations for antibiotic prophylaxis are sometimes inadequate. Objective - The aim of this study was to analyze the effect of three prophylactic antibiotic regimens on the incidence of surgical site infection. Methods - A prospective, cross-sectional study was conducted between January 2009 and January 2013 in which 896 Roux-en-Y gastric bypasses were performed to treat obesity. The study compared three groups of patients according to the perioperative antibiotic prophylaxis administered intravenously and beginning at anesthesia induction: Group I consisting of 194 patients treated with two 3-g doses of ampicillin/sulbactam; Group II with 303 patients treated with a single 1-g dose of ertapenem; and Group III with 399 patients treated with a 2-g dose of cefazolin at anesthesia induction followed by a continuous infusion of cefazolin $1 \mathrm{~g}$ throughout the surgical procedure. The rate of surgical site infection was analyzed, as well as its association with age, sex, preoperative weight, body mass index and comorbidities. Results - The rates of surgical site infection were $4.16 \%$ in the group treated prophylactically with ampicillin/sulbactam, $1.98 \%$ in the ertapenem group and $1.55 \%$ in the continuous cefazolin group. Conclusion - The prophylactic use of continuous cefazolin in surgeries for morbid obesity shows very promising results. These findings suggest that some prophylactic regimens need to be reconsidered and even substituted by more effective therapies for the prevention of surgical site infections in bariatric patients.
\end{abstract}

HEADINGS - Infection. Bariatric surgery. Cefazolin. Gastroplasty. Obesity.

\section{INTRODUCTION}

As obesity reaches current pandemic proportions, the number of bariatric surgeries also increases worldwide. This surgical treatment has been consolidated as an effective therapy for obesity and for the long-term maintenance of weight loss. Nevertheless, surgery for obesity has been associated with some early and late complications that account for significant morbidity. The major villain in this group of complications is infection; therefore, prevention is paramount in the management of these patients.

For infection prophylaxis to be successful, the spectrum, pharmacokinetics and toxicity of the selected antimicrobial agents need to be taken into consideration, as well as other factors such as the appropriate duration of therapy and the maximum concentration of the drug in the tissues at the time of the incision ${ }^{(5,10,13)}$. However, the currently available guidelines on antibiotic prophylaxis are based on healthy, non-obese patients.

The literature in general, and that related to obese surgical patients in particular, is sparse with respect to the use of antibiotics and their distribution in the body of obese patients. Little is known on the pharmacokinetics of antibiotics in patients whose body mass index (BMI) is $>40 \mathrm{~kg} / \mathrm{m}^{2}$ (9). Even so, the manner in which obese patients absorb, distribute, metabolize and excrete drugs in general is known to be different from that of non-obese individuals.

Indeed, the relationship between body size and physiological and pharmacokinetic variables in the obese population $^{(1,2,6,9)}$ implies that some physiological changes that are characteristic of morbid obesity affect the kinetics of drugs. These changes involve an increase in cardiac output, total blood volume and renal clearance, as well as the occurrence of fat deposits in the liver and changes in plasma proteins. 
Taking into consideration that the incidence of surgical site infection in patients operated on for morbid obesity is high and the current recommendations for prophylactic antibiotics are flawed ${ }^{(7)}$, with surgical site infection tending to result in significant morbidity, it is assumed that the current prophylactic regimens probably fail to provide adequate tissue levels of the drugs in the morbidly obese. Therefore, this study was conducted to analyze the rates of surgical site infection (SSI) with three different antibiotic prophylactic regimens.

\section{METHODS}

A prospective, cross-sectional study including a total of 896 Roux-en-Y gastric bypasses performed to treat obesity was conducted between January 2009 and January 2013 at the Hospital of the Federal University of Pernambuco, Northeastern Brazil (Table 1). The institute's internal review board approved the study protocol prior to its initiation and all patients signed an informed consent form.

All the procedures were performed by laparotomy. The study analyzed the rate of SSI according to the prophylactic regimen used and also evaluated associations with other factors such as age, sex, preoperative weight, BMI and comorbidities.

At admission, patients were examined to rule out any possible sites of infection and to identify any community-acquired infection, with the procedure being cancelled if any were found. Two hours prior to surgery, patients were asked to take a shower and wash their hair, after which the surgical site was washed using a chlorhexidine solution. Trichotomy was performed after anesthesia was induced. After a skin incision was made, subcutaneous tissue was carefully retracted, limiting injury to as few adipocytes as possible and minimizing the risk of developing a seroma. The aponeurosis was closed using continuous absorbable sutures. The subcutaneous tissue was sutured to diminish the dead space. No drains were used in the subcutaneous tissue. In all cases, the skin was closed by suturing.

The study compared three groups of patients according to infection prophylaxis, with the antibiotics being administered intravenously at the induction of anesthesia in all cases $^{(10,13,17)}$. In Group I, 194 patients were treated with two doses of ampicillin (2.0 grams) / sulbactam (1.0 gram); in the 303 patients in Group II, treatment consisted of a single 1-gram dose of ertapenem; and the 399 patients in Group III received a single 2-gram dose of cefazolin at induction of anesthesia followed by a continuous infusion of $1 \mathrm{gram}$ of cefazolin throughout the surgical procedure. Patients were followed up for a minimum of 30 days to diagnose and control any possible infections ${ }^{(12,14)}$. The presence of pus was the criterion used to classify the wound as infected. Whenever infection was detected at the surgical site, the wound was opened. Dressings were changed daily. Seromas were managed by manual expression, without need to reopen the wound.

The data were presented as tables of frequency distribution. Means and medians were calculated and the chi-square test was used to evaluate differences at a significance level of $95 \%(P<0.05)$.

\section{RESULTS}

The most common surgical complications recorded were related to the surgical site No patients had to be re-operated and no deaths occurred as a result of these complications. There were no statistically significant differences between the three groups with respect to surgical site infection (Table 2). The Frequency of postoperative complications according to the type of antibiotic prophylaxis used were no statistically

TABLE 2. Rate of surgical site infection according to the type of antibiotic prophylaxis used for bariatric surgery

\begin{tabular}{lccc}
\hline Patients who developed wound infection & Total & $\mathrm{n}$ & $\%$ \\
\hline Group I & & & \\
$\quad$ Ampicillin/sulbactam & 194 & 08 & $4.12 \%$ \\
Group II & & & \\
$\quad$ Ertapenem & 303 & 06 & $1.98 \%$ \\
$\quad$ Group III & & & \\
$\quad$ Continuous cefazolin & 399 & 06 & $1.50 \%$ \\
$\quad$ Total & 896 & 16 & $1.78 \%$ \\
\hline
\end{tabular}

Group I versus Group II: $P=0.371$; Group I versus Group III: $P=0.143$; Group II versus Group III: $P=0.890$.

TABLE 1. Patient-related variables according to the type of antibiotic prophylaxis used for bariatric surgery

\begin{tabular}{lccc}
\hline Variable & $\begin{array}{c}\text { Ampicillin/sulbactam } \\
(\mathbf{n}=194)\end{array}$ & $\begin{array}{c}\text { Ertapenem } \\
(\mathbf{n}=303)\end{array}$ & $\begin{array}{c}\text { Continuous Cefazolin } \\
(\mathbf{n}=399)\end{array}$ \\
\hline Females & $116(59.8 \%)$ & $181(59.7 \%)$ & $248(62.2 \%)$ \\
Males & $78(40.2 \%)$ & $122(41.3 \%)$ & $151(37.8 \%)$ \\
Mean age (range) (years) & $33.1(16-61)$ & $34.7(20-64)$ & $35.1(16-70)$ \\
Mean weight (range) $(\mathrm{kg})$ & $124.8(86-215)$ & $136.2(87-232)$ & $136.9(85-202)$ \\
Mean BMI (range) $\left(\mathrm{kg} / \mathrm{m}^{2}\right)$ & $43(35-79)$ & $45(33-72)$ & $45(33-65)$ \\
Comorbidities & $139(71.6 \%)$ & $205(67.6 \%)$ & $278(69.7 \%)$ \\
\hline
\end{tabular}


significant differences between the groups (Table 3). No adverse reactions occurred during the study that could be attributed to the antimicrobial agents used as prophylaxis.

\section{DISCUSSION}

Recommendations regarding the prophylactic treatment of infection in obese patients are currently identical to those adopted for non-obese patients. The guidelines issued by the Centers for Disease Control and Prevention (CDC) in 1999 recommend the prophylactic use of antibiotics, administered intravenously to ensure peak plasma concentrations at the time of incision, maintaining therapeutic blood and tissue levels throughout surgery and up to a few hours after skin closure $^{(9,17)}$.

Drugs are absorbed, distributed, metabolized and excreted differently in obese compared to non-obese patients. Few data are available in the literature with respect to pharmacotherapy in obese patients and the available data are limited to only a few drugs. As with anesthetics, chemotherapy drugs and certain other drugs, antimicrobials may be significantly affected by obesity and by changes determined by surgical procedures $^{(9,12,14)}$.

The volume and the speed of distribution of drugs are determined by many factors including body mass, blood flow to the tissues, tissue protein binding and the kinetics of drug excretion. The relative importance of each of these factors varies with the physical and chemical characteristics of the drug, including its lipid solubility. Most antimicrobial substances are polar, or hydrophilic, meaning that they are easily distributed in water but not in adipose tissue.

Surgical site infections develop in $5.6 \%-20 \%$ of patients undergoing gastroplasty when cefazolin is administered prophylactically. The incidence of surgical site infections in patients operated on for obesity is high and there is a need to establish recommendations for antibiotic prophylaxis in this population $^{(7)}$. For this reason, since 1997 this research group has been involved in studying safe and effective prophylaxis.

The water content of adipose tissue is approximately $30 \%$ that of other tissues. Consequently, the volume of distribution of hydrophilic drugs in this type of tissue may be around $30 \%$ of that found in other tissues. The distribution of hydrophilic antimicrobials in the water content of adipose tissue explains the need to increase the dose proportionally to compensate for excess body weight, using the dose correction factor for the patient's weight ${ }^{(19)}$. In individuals who are underweight or of normal weight, blood flow in adipose tissue is low and represents around 5\% of cardiac output, whereas in obese individuals, fat tissue blood flow reaches $22 \%$ of cardiac output ${ }^{(16)}$.

Unlike other antibiotics, the pharmacokinetics of vancomycin and aminoglycosides has been extensively evaluated in the obese population. The interval between doses should be individualized by measuring the serum concentrations of these drugs ${ }^{(4)}$. The maximum plasma concentration of ciprofloxacin is lower in obese compared to non-obese patients following a 400-mg intravenous infusion of this drug; however concentrations remain within the recommended therapeutic range ${ }^{(3)}$.

In a study conducted by Edmiston et al., patients submitted to Roux-en-Y gastric bypasses for morbid obesity were given 2 grams of cefazolin preoperatively followed by a second dose three hours later. Thirty-eight patients were assigned to one of three groups according to their BMI: A) 40-49 $(\mathrm{n}=17)$, B) $50-59(\mathrm{n}=11)$ and C) $\geq 60 \mathrm{~kg} / \mathrm{m}^{2}(\mathrm{n}=10)$. Multiple timed serum and tissue samples were collected and cefazolin levels were assessed by microbiological assay. Significantly lower concentrations of cefazolin were found in the adipose closure $(P=0.04)$, initial $(P=0.03)$ and omental flap closure $(P=0.05)$ in groups $\mathrm{B}$ and $\mathrm{C}$ compared to group A. Therapeutic tissue levels were achieved in only $48.1 \%$, $28.6 \%$ and $10.2 \%$ of the specimens in groups A, B and C, respectively ${ }^{(8)}$.

In a study carried out by Forse et al., morbidly obese patients submitted to gastroplasty were randomly selected to receive 1 gram of cefazolin either into the fatty tissue of the gluteal region, intramuscularly in the gluteal region or by intravenous injection, while a fourth group of morbidly obese patients were given 2 grams of cefazolin intravenously. At incision and closure, both blood and tissue levels of cefazolin were significantly $(P<0.001)$ lower in all the morbidly obese patients who received 1 gram of cefazolin compared to the blood and tissue levels of the drug found in patients of normal weight. Cefazolin levels below the minimum inhibitory

TABLE 3. Frequency of postoperative complications according to the type of antibiotic prophylaxis used for bariatric surgery

\begin{tabular}{|c|c|c|c|c|c|c|c|c|}
\hline \multirow[t]{2}{*}{ Complications } & \multicolumn{2}{|c|}{$\begin{array}{l}\text { Ampicillin/ } \\
\text { sulbactam }\end{array}$} & \multicolumn{2}{|c|}{ Ertapenem } & \multicolumn{2}{|c|}{ Continuous Cefazolin } & \multicolumn{2}{|l|}{ Total } \\
\hline & $\mathrm{n}$ & $\%$ & $\mathrm{n}$ & $\%$ & $\mathrm{n}$ & $\%$ & $\mathrm{n}$ & $\%$ \\
\hline Seroma & 76 & 39.2 & 15 & 37.9 & 151 & 37.8 & 342 & 38.2 \\
\hline Atelectasis & 09 & 4.6 & 19 & 6.3 & 18 & 4.5 & 46 & 5.1 \\
\hline Respiratory infection & 05 & 2.6 & 03 & 1.0 & 5 & 0.7 & 13 & 1.4 \\
\hline Urinary tract infection & 03 & 1.5 & 06 & 2.0 & 5 & 1.2 & 14 & 1.6 \\
\hline Gastric fistula & 03 & 1.5 & 01 & 0.3 & 3 & 0.7 & 7 & 0.8 \\
\hline Thromboembolism & 02 & 1.0 & 03 & 1.0 & 2 & 0.5 & 10 & 1.1 \\
\hline Intra-abdominal infection & 03 & 1.5 & 03 & 1.0 & 3 & 0.7 & 9 & 1.0 \\
\hline Postoperative death & 0 & - & 0 & - & 1 & 0.2 & 1 & 0.1 \\
\hline
\end{tabular}


concentration of $>2$ micrograms $/ \mathrm{mL}$ for gram-positive cocci and $>4$ micrograms $/ \mathrm{mL}$ for gram-negative rods were found. When the morbidly obese patients were given 2 grams of cefazolin, the incidence of surgical site infection fell from $16.5 \%$ to $5.6 \%$; therefore, the recommended dose of cefazolin for the morbidly obese patient was increased from 1 to 2 grams $^{(15)}$.

Ferraz et al. evaluated two groups of patients undergoing Roux-en-Y gastric bypasses in a study in which patients receiving two 3-gram doses of ampicillin-sulbactam as antimicrobial prophylaxis were compared with patients receiving a single 1-gram dose of ceftriaxone. No statistically significant differences were found between these two groups with respect to the incidence of surgical site infection ${ }^{(11)}$.

In a study conducted by van Kralingen et al., younger age rather than body weight was shown to be associated with a significantly higher clearance of cefazolin. However, since the unbound plasma concentrations of cefazolin remained above $1 \mathrm{mg} \mathrm{L(-1)} \mathrm{in} \mathrm{all} \mathrm{patients} \mathrm{weighing} \leq 260 \mathrm{~kg}$ up to 4 hours after intravenous administration of a 2-gram dose, repeating the dose within 4 hours of administration or giving the patients a dose of another class of antibiotic should only be considered in the case of a higher minimum inhibitory concentration for $90 \%$ of the isolates tested ${ }^{(18)}$.
Current analysis of pharmacokinetic dosing suggests that the strategies adopted may fail to provide adequate perioperative prophylaxis in gastric bypass patients. The results of the present study show rates of surgical site infection that range from $4.16 \%$ when prophylaxis with ampicillin-sulbactam is used to $1.98 \%$ when ertapenem is used and $1.55 \%$ with continuous cefazolin. The use of continuous cefazolin as prophylaxis during the surgical treatment of morbid obesity has shown very promising results. However, further studies are required to evaluate the effect of this therapy on hospital microflora and bacterial resistance. Therefore, based on these findings, some prophylactic regimens should be reconsidered and even substituted to ensure the prevention of surgical site infection in bariatric patients.

\section{Authors' contributions}

Ferraz AAB: literature review, data analysis, preparation of the manuscript; Siqueira LT: survey data, data analysis; Campos JM: survey data, data analysis; Araújo Jr GC: literature review, data analysis, preparation of the manuscript; Martins Filho ED: literature review, survey data, data analysis, preparation of the manuscript; Ferraz EM: survey data, data analysis.

Ferraz AAB, Siqueira LT, Campos JM, Araújo Junior GC, Martins Filho ED, Ferraz EM. Antibioticoprofilaxia em cirurgia bariátrica: infusão contínua de cefazolina versus ampicilina/sulbactam e ertapenem. Arq Gastroenterol. 2015,52(2):83-7.

RESUMO - Contexto - A incidência de infecção de sítio cirúrgico em pacientes bariátricos é significativa e as recomendações atuais para a profilaxia antibiótica são por vezes inadequadas. Objetivo - O objetivo deste estudo foi analisar o efeito de três esquemas de antibióticos profiláticos sobre a incidência de infecção de sítio cirúrgico. Método - Estudo prospectivo, transversal, foi realizado entre janeiro de 2009 e janeiro de 2013 , em que 896 derivações gástricas em Y de Roux foram realizadas para tratar a obesidade. O estudo comparou três grupos de pacientes de acordo com a profilaxia antibiótica administrada no perioperatória por via intravenosa, iniciada na indução anestésica: Grupo I constituído de 194 pacientes tratados com duas doses de $3 \mathrm{~g}$ de ampicilina/sulbactam; Grupo II com 303 pacientes tratados com uma única dose de $1 \mathrm{~g}$ de ertapenem; e Grupo III com 399 pacientes tratados com uma dose de $2 \mathrm{~g}$ de cefazolina no momento da indução da anestésica seguida de uma infusão contínua de cefazolina $1 \mathrm{~g}$ durante o procedimento cirúrgico. A taxa de infecção de sítio cirúrgico foi analisada, bem como a sua associação com a idade, sexo, peso pré-operatório, o índice de massa corporal e comorbidades. Resultados - As taxas de infecção do sítio cirúrgico foram de 4,16\% no grupo tratado profilaticamente com ampicilina/sulbactam, 1,98\% no grupo de ertapenem e 1,55\% no grupo de cefazolina contínua. Conclusão - O uso profilático de cefazolina contínua em cirurgias para obesidade mórbida apresenta resultados muito promissores. Estes resultados sugerem que alguns regimes profiláticos precisam ser reconsiderados e até mesmo substituídos por terapias mais eficazes para a prevenção de infecções de sítio cirúrgico em pacientes bariátricos.

DESCRITORES - Infecção. Cirurgia bariátrica. Cefazolina. Gastroplastia. Obesidade. 


\section{REFERENCES}

1. Abernethy DR, Greenblatt DJ. Phamacokinetics of drugs in obesity. Clin Pharmacokinet. 1982;7(2):108-124.

2. Abernethy DR, Greenblatt DJ. Drug disposition in obese humans. An update. Clin Pharmacokinet. 1986;11(3):199-213.

3. Allard S, Kinzig M, Boivin G, Sörgel F, LeBel M. Intravenous ciprofloxacin disposition in obesity. Clin Pharmacol Ther. 1993;54(4):368-73.

4. Bearden DT, Rodvold KA. Dosage adjustments for antibacterials in obese patients applying clinical pharmacokinetics. Clin Pharmacokinet. 2000;38(5):415-26.

5. Burke JF. The effective period of preventive antibiotic action in experimental incisions and dermal lesions. Surgery. 1961;50:161-8.

6. Cheymol G. Clinical pharmacokinetics of drugs in obesity. An update. Clin Pharmacokinet. 1993;25(2):103-14

7. Christou NV, Jarand J, Sylvestre JL, McLean AP. Analysis of the incidence and risk factors for wound infections in open bariatric surgery. Obes Surg. 2004;14(1):16-22.

8. Edmiston CE, Krepel C, Kelly H, Larson J, Andris D, Hennen C, et al. Perioperative antibiotic prophylaxis in the gastric bypass patient: do we achieve therapeutic levels? Surgery. 2004;136(4):738-47.

9. Ferraz AA, Albuquerque AC. Farmacocinética no tratamento cirúrgico da obesidade mórbida. In: Garrido Jr. A, Ferraz EM, Barroso FL, et al. Cirurgia da obesidade. São Paulo: Atheneu; 2002. p.135-40.

10. Ferraz AA, Ferraz EM. Antibioticoprofilaxia em cirurgia. Programa de Atualização do Colégio Brasileiro de Cirurgiões. Rio de Janeiro: Colégio Brasileiro de Cirurgiões; 2002. p.4-18.
11. Ferraz AA, Arruda PC, Albuquerque AC, et al. [Comparative study of ampicillin / sulbactam and ceftriaxone in the prophylaxis for bariatric surgery]. Rev Bras Med 2003;60:617-621.

12. Ferraz EM, Ferraz AA, Coelho HS, Pereira Viana VP, Sobral SM, Vasconcelos MD, Bacelar TS. Postdischarge surveillance for nosocomial wound infection: does judicious monitoring find cases? Am J Infect Control. 1995;23(5):290-4.

13. Ferraz EM, Ferraz AA. Antibioticoprofilaxia. In: Ferraz EM, ed. Infecção em cirurgia. Rio de Janeiro: MEDSI; 1997. p.345-52.

14. Ferraz EM, Ferraz, AA, Bacelar TS, et al. [Infection control in general surgery: results of a prospective study of 23 years in 42,274 surgeries]. Rev Col Bras Cir. 2001;28:17-26.

15. Forse RA, Karam B, MacLean LD, Christou NV. Antibiotic prophylaxis for surgery in morbidly obese patients. Surgery.1989;106(4):750-6.

16. Lesser GT, Deutsch S. Measurement of adipose tissue blood flow and perfusion in man by uptake of 85Kr. J Appl Physiol. 1967;23(5):621-30.

17. Mangram AJ, Horan TC, Pearson ML, et al. Guideline for prevention of surgical site infection, 1999. Hospital Infection Control Practices Advisory Committee. Infect Control Hosp Epidemiol 1999;20(4):247-78.

18. van Kralingen S, Taks M, Diepstraten J, van de Garde EM, van Dongen EP, Wiezer MJ, et al. Pharmacokinetics and protein binding of cefazolin in morbidly obese patients. Eur J Clin Pharmacol, 2011;67(10):985-92.

19. Wurtz R, Itokazu G, Rodvold K. Antimicrobial dosing in obese patients. Clin Infect Dis. 1997;25(1):112-8.

Received 27/12/2014 Accepted 24/2/2015 